DOI: http://dx.doi.org/10.33846/hn31103

http://heanoti.com/index.php/hn

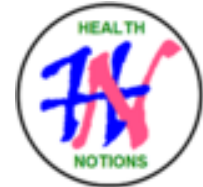

RESEARCH ARTICLE

URL of this article: http://heanoti.com/index.php/hn/article/view/hn31103

\title{
Sputum Conversion is Faster with Vitamin D Suplementation in Pulmonary TB Patients
}

\author{
Nita Andriani Lubis ${ }^{1(\mathrm{CA})}$, Gabriella Septiani Nasution ${ }^{2}$ \\ ${ }^{1(\mathrm{CA})}$ Department of Medical Laboratory Technology, Poltekkes Kemenkes Medan, Indonesia; \\ nita.andriani.lubis@gmail.com (Corresponding Author) \\ ${ }^{2}$ Department of Medical Laboratory Technology, Poltekkes Kemenkes Medan, Indonesia
}

\begin{abstract}
Pulmonary tuberculosis (TB) is still a problem that must be resolved in Indonesia, especially North Sumatra. The study aims to determine the effect of vitamin D supplementation on the speed of sputum conversion in pulmonary TB patients. Randomized controlled trial study was conducted on 41 pulmonary TB patients according to inclusion criteria. Research subjects were given TB drug (DOTS program) and vitamin D treatment for 2 months. Sputum examination based on smear was carried out microscopically at $2 \mathrm{nd}$ week, $4 \mathrm{nd}$ week, $6 \mathrm{nd}$ week, and 8nd week after treatment. The results showed that all pulmonary TB patients who were given the intervention experienced sputum conversion. Research subjects with AFB +1 occurred the fastest conversion compared to the others. Statistical analysis using chi square obtained significant results $(\mathrm{p}=0.0001)$. Sputum conversion evaluation based on the initial AFB status, there was a significant relationship between the time of sputum conversion with the initial AFB status with a very strong correlation level $(r=0.767)$. Vitamin D has been shown to have a significant effect on the patient's sputum conversion.
\end{abstract}

Keywords: pulmonary TB; vitamin D; sputum conversion

\section{INTRODUCTION}

\section{Background}

WHO noted that Indonesia in 2018 was still ranked third (10\%) in the world after India (25\%) and Nigeria $(12 \%)^{(1)}$. The results of the Basic Health Research (Riskesdas) in 2018, prevalence of TB based on a diagnosis of 759 per 100,000 population for ages 15 and older. Pulmonary TB is still a problem that must be resolved as written in the RPJMN of Ministry of Health Indonesia in 2015-2019. Prevalence of TB is based on a diagnosis of $0.4 \%$ of the total population in North Sumatra, which means there are 400 people diagnosed with pulmonary TB per 100,000 population. ${ }^{(2)}$ Population census data of the Central Statistics Agency of Medan as the capital of North Sumatra has an area of $261.5 \mathrm{~km}^{2}$, with a population of 2,983,868 people and a population density of 8,008 people $/ \mathrm{km}^{2}$. ${ }^{(3)}$

Treatment of TB patients with vitamin D supplementation has been carried out in several populations in Indonesia Jakarta, Malang, and Wonosobo with the results of accelerating sputum conversion ${ }^{(4-6)}$. Vitamin D plays a key role in increasing the natural immunity of TB patients against TB germs. Low vitamin D levels in a person's body indicate a low body defense ability against M. tuberculosis infection in several studies. Vitamin D is one of the mediators that can inhibit the growth of M. tuberculosis in macrophages and monocytes ${ }^{(7)(8)}$.

The solution to overcome the problem of TB is mostly done with preventive measures rather than curative. This method is considered more effective, because TB germs have a risk of becoming resistant during the treatment process. Research on TB patients has also linked genetic problems of TB patients such as vitamin 
D receptors. Vitamin D receptor genes (FokI, BsmI, TaqI, ApaI) are associated with a person's susceptibility to the risk of TB infection. ${ }^{(9-12)}$

The results of this study are expected to add research evidence on suplementation of vitamin D in the treatment of pulmonary TB patients. It can be used as evidence in policy making by the government in the use of vitamin D as an additional supplement for TB patients. This study aims to provide the effect of vitamin D supplementation on the speed of sputum conversion in pulmonary TB patients

\section{METHODS}

The experimental study used a randomized controlled trial design in pulmonary TB patients. The main inclusion criteria chosen as the study subjects were new cases of pulmonary TB patients with smear positive direct smear sputum, age $\geq 15$ years, willing to follow the study by signing informed consent. This research was conducted from March-October 2019. The research sample was collected in 2 (two) Puskesmas in the Deli Serdang working area (Puskesmas Pancurbatu and Puskesmas Muliorejo) with consecutive sampling method.

Subjects who met the inclusion criteria were interviewed, and given pots of sputum for each subject to take sputum at weeks 2,4,6 and 8 in the morning. $80 \mathrm{~TB}$ patients who met the inclusion criteria were given TB drugs and oral vitamin $\mathrm{D}_{3}$ cholecalciferol (Biotech) treatment at week 8, 0.2.4, and 6. Dose of vitamin $\mathrm{D}$ given 100,000 iu with four times the administration at week 0,2,4 and week 6 . Sputum TB patients are taken to the public health center to be examined when taking TB drugs.

Researchers worked with TB officers to schedule the taking of TB drugs that were the subject of research every 2 weeks according to the schedule for vitamin D and sputum examination, so that researchers made sure the subjects took vitamin D. Sputum is examined by the puskesmas laboratory staff where the patient is treated. Kruskal Wallis and Mann Whitney test was performed to assess the effect of vitamin D administration on sputum conversion. This study has passed the ethical review from the health research ethics commission agency.

\section{RESULTS}

\section{Subject Characteristics}

Based on the result of the research on 82 subjectss being treated in the Puskesmas Pancurnatu and Puskesmas Muliorejo, Deli Serdang, for pulmonary TB patients using TB drugs with vitamin D and only TB drugs, it was found that.

From the Table 1, Table 2, Table 3 and Table 4, it could be found that TB patients with vitamin D suplementation based on characteristics with highest frequency is with male sex (58.5\%), an age range of 26-45 years, Toba tribe (31.7\%), AFB +1 status (70.7\%); while TB patients without vitamin D suplementation with male sex $(65.9 \%)$, an age range of 46-65 years, Toba tribe $(56.1 \%)$, AFB +2 status $(48.8 \%)$.

Table 1. Distribution of TB patients based on gender

\begin{tabular}{ccccc}
\hline Gender & \multicolumn{2}{c}{ With vitamin D } & \multicolumn{2}{c}{ Without vitamin D } \\
\cline { 2 - 5 } & Frequency & Percentage & Frequency & Percentage \\
\hline Male & 24 & 58.5 & 27 & 65.9 \\
Female & 17 & 41.5 & 14 & 34.1 \\
\hline
\end{tabular}

Table 2. Distribution of TB patients based on age

\begin{tabular}{ccccc}
\hline Age & \multicolumn{2}{c}{ With vitamin D } & \multicolumn{2}{c}{ Without vitamin D } \\
\cline { 2 - 5 } & Frequency & Percentage & Frequency & Percentage \\
\hline Adolescent (12-25) years & 9 & 22.0 & 6 & 14.6 \\
Adult (26-45) years & 20 & 48.8 & 17 & 41.5 \\
Elderly (46-65) years & 10 & 24.4 & 18 & 43.9 \\
Old man (>65 years) & 2 & 4.9 & 0 & 0 \\
\hline
\end{tabular}


Table 3. Distribution of TB patients based on health center

\begin{tabular}{ccccc}
\hline Health center & \multicolumn{2}{c}{ With Vitamin D } & \multicolumn{2}{c}{ Without Vitamin D } \\
\cline { 2 - 5 } & Frequency & Percentage & Frequency & Percentage \\
\hline Health center "Pancurbatu" & 14 & 34.1 & 20 & 48.8 \\
Health center "Muliorejo" & 27 & 65.9 & 21 & 51.2 \\
\hline
\end{tabular}

Table 4. Distribution of TB patients based on AFB status

\begin{tabular}{cccccc}
\hline AFB status & \multicolumn{2}{c}{ With vitamin D } & \multicolumn{2}{c}{ Without vitamin D } \\
\cline { 2 - 5 } & Frequency & Percentage & Frequency & Percentage \\
\hline$\bullet$ & +1 & 29 & 70.7 & 7 & 17.1 \\
$\bullet$ & +2 & 7 & 17.1 & 20 & 48.8 \\
$\bullet$ & +3 & 5 & 12.2 & 14 & 34.1 \\
\hline
\end{tabular}

\section{Sputum Conversion Time}

Table 5. sputum conversion time difference in both groups

\begin{tabular}{ccccc}
\hline \multirow{2}{*}{$\begin{array}{c}\text { Sputum conversion } \\
\text { time }\end{array}$} & $\begin{array}{c}\text { With } \\
\text { Vitamin D }\end{array}$ & $\begin{array}{c}\text { Without } \\
\text { Vitamin D }\end{array}$ & Mean Rank & p \\
\cline { 2 - 4 } $\begin{array}{c}\text { Not conversion } \\
2^{\text {nd }} \text { week }\end{array}$ & 0 & 4 & 2.5 & \\
$4^{\text {nd }}$ week & 18 & 1 & 14.0 & \\
$6^{\text {nd }}$ week & 15 & 19 & 40.5 & 0.000 \\
$8^{\text {nd }}$ week & 5 & 11 & 64.5 & \\
\hline
\end{tabular}

The results in table 5, sputum of all pulmonary TB patients in the group with vitamin D supplementation were all conversion, while the group without vitamin D supplementation there were 4 people who did not convert within two months of treatment.

Data continued with mann whitney test with test results as in the table 3.

Table 3. mann whitney test results based on sputum conversion time

\begin{tabular}{|c|c|c|c|c|}
\hline & Mann Whitney U & Wilcoxon W & $\mathrm{Z}$ & $\begin{array}{c}\text { Asymp.Sig. } \\
\text { (2-tailed) }\end{array}$ \\
\hline $2^{\text {nd }}$ week- $4^{\text {nd }}$ week & 0.000 & 171.000 & -5.657 & 0.000 \\
\hline $2^{\text {nd }}$ week- $6^{\text {nd }}$ week & 0.000 & 171.000 & -4.472 & 0.000 \\
\hline $2^{\text {nd }}$ week- $8^{\text {nd }}$ week & 0.000 & 171.000 & -4.690 & 0.000 \\
\hline $4^{\text {nd }}$ week- $6^{\text {nd }}$ week & 0.000 & 120.000 & -4.123 & 0.000 \\
\hline $6^{\text {nd }}$ week- $8^{\text {nd }}$ week & 0.000 & 120.000 & -4.359 & 0.000 \\
\hline
\end{tabular}


Mann Whitney-U test results show that vitamin D supplementation given to TB patients is more effective at $4^{\text {nd }}$ and $6^{\text {nd }}$ week.

\section{DISCUSSION}

\section{Characteristics of Subjects}

Subjects with male sex more than female sex in two groups. This is influenced by the lifestyle of them. Men are head of families who work for a living with more activities outside than women. Men are mostly active smokers, which can be a risk factor for lung TB infection. According to the results of regional health research in 2018 the number of smokers in Indonesia increased from 7.2 in 2013 to 9.1 in 2018 . Other risk factors are high alcohol consumption, alcoholic beverages consumption is more carried out by men than women. ${ }^{(13)}$ The results of our brief interviews with several subjects showed that habitual consumption of alcoholic beverages was common in his daily life before suffering from pulmonary TB.

Based on the age of subjects, the adult group with an age range of 26-45 years more than the other in the group with vitamin D supplementation, while in the group without vitamin D 46-65 years more than the other. Basic health research data (Riskesdas) in 2013 recorded the age of pulmonary TB patients in Indonesia at most ages $24-34$ years by $21.4 \%$, ages $35-44$ years $19.41 \%$ and ages $45-54$ years $19.39 \%$. WHO in the Global Tuberculosis Report 2018 reported the most TB incidents in Indonesia at the age of 25-34 years both in male and female sex. ${ }^{(1,14)}$

The difference in the number of pulmonary TB patients by age of study subjects is due to the physiological processes of the body that are different in each age range. The role of hormone interactions with pulmonary TB infection is one of the physiological processes of the body that is different at the age level. The results of previous studies found an interaction between dehydroepiandrosterone (DHEA) with glucokaoticoids which affect several lymphocyte functions. Active TB disease is characterized by decreased DHEA levels and elevated cortisol levels. Disruption of the ratio of cortisol to DHEA results in changes in the concentration of key cytokines in TB, namely gamma interferon. ${ }^{(15)}$

\section{Sputum Conversion Time (With Vitamin D Suplementation)}

To help diagnose tuberculosis (TB) and infections caused by other Mycobacterium species, which are known as acid-fast bacilli (AFB). AFB smear refers to the microscopic examination of a fluorochrome stain of a clinical specimen, with the results of $\mathrm{AFB}+1$ (few), $\mathrm{AFB}+2$ (moderate) and $\mathrm{AFB}+3$ (many) of TB germs. The AFB sputum conversion time was measured every 2 weeks after the subjects were given the intervention of TB drugs and vitamin $\mathrm{D}$. The number of subjects who converted in the group with suplementation vitamin $\mathrm{D}$ were subjects with AFB +1 status was 29 people, $\mathrm{AFB}+2$ were 7 people and AFB +3 were 5 people. The results of the examination showed smear pulmonary TB patients +1 experienced conversion at 2 nd week (18 people) and 4nd week (11 people), AFB+ 2 conversion time at 4 nd week (4 people) and 6 nd week ( 3 people), AFB +3 all had conversions in the 8 nd week (5 people).

Vitamin D is an organic substance that is less soluble in water, and very soluble in fat. The biomarker of vitamin D status is 25-hydroxyvitamin D3 with active metabolite 1,25- $(\mathrm{OH}) \mathrm{D}$. The role of vitamin $\mathrm{D}$ in the body including increases bone mineralization, decreases PTH syntesis and release, increases absorption of calcium and phosphate, induces differentiation in immune cells, improves hematopoiesis, and inhibits clonal proliferation. The role of vitamin D is very important in the body's defense against TB through its action on increasing phagocytosis of macrophages. Vitamin D, either endogenously (Vitamin D3) or consumed (vitamin D2 or vitamin D3), must be activated to produce an effect. In the case of TB using anti-tuberculosis drugs, it makes TB resistant in some patients, vitamin D as an immunomodulatory hormone is used as one of the healing therapies. ${ }^{(16-19)}$

Calcitrol as an active metabolite of vitamin D has antibacterial activity, this metabolite modulates host response to mycobacterial infections by inducing reactive nitrogen and oxygen intermediates, inhibiting matrix metalloproteinase enzymes that play a role in the cavity formation process by upregulating IL-10 receptors thereby inducing IL-10 synthesis, and induces the antimicrobial activity of cathelicidin which induces autophagi. ${ }^{(5,19-21)}$

\section{Sputum Conversion Time (Without Vitamin D Suplementation)}


Results of sputum conversion in the group treated without vitamin D supplementation, there were 4 people who did not convert with initial $\mathrm{AFB}+2$ and $\mathrm{AFB}+3$ status. Subjects with $\mathrm{AFB}+1$ conversion at 2 weeks ( 1 person), 4 weeks ( 4 people), and 6 weeks ( 2 people). Subjects with AFB +2 conversions at week 4 (9 people), week 6 (6 people), and week 8 ( 3 people). Subjects with AFB + 3 conversions at week 4 were 96 people, week 6 (3 people), and week 8 ( 3 people).

Patients with TB have low levels of vitamin D in their bodies when compared to healthy populations. Research in Spain says that people who are more often associated with TB patients have low $25(\mathrm{OH}) \mathrm{D}$ levels and this is thought to be due to the body's immune process against tuberculosis. Other studies in India prove that vitamin $\mathrm{D}$ is associated with susceptibility to TB and the risk of developing infection to TB disease. Similar results in Pakistan with a cohort design in 129 patients proved vitamin D deficiency increased the risk of developing TB. ${ }^{(22-24)}$

There were 4 TB patients who were not converted in the group without vitamin D supplementation, TB patients who have consumed TB drugs and supplemented it will provide resistance to M. tunerculosis germs theoretically $(7,18)$ The response of some $\mathrm{M}$. tuberculosis germs besides dying against the host immune system will be responded to by doing dormancy. Research in India states that the number of more TB bacilli in AFB +3 has a higher risk of developing drug-resistant mutants than $\mathrm{AFB}+2$ and $\mathrm{AFB}+1 .^{(25)}$

\section{Assessed the speed of sputum conversion in both groups}

AFB sputum examination with a microscope is the main diagnostic supporting examination in developing countries. This examination is the most effective (efficient), easy, inexpensive, and fast, while the culture examination is a gold standard examination to determine the diagnosis of TB. One indicator used to monitor and assess treatment (evaluation of therapy) is to look at sputum conversion. Sputum conversion is a change (conversion) of sputum examination results of smear positive pulmonary TB patients into negative AFB after undergoing a period of treatment or intensive therapy. ${ }^{(26,27)}$

The results of this study showed that all pulmonary TB patients given intervention (suplementasion vitamin D) had sputum conversion. Subjects with the most initial AFB +1 status conversions at 2nd weeks, AFB +2 at 4 nd weeks, and AFB +3 at 8 nd weeks. This is in line with previous studies conducted by Parikh et al., 2012 in India, stating that AFB +3 pulmonary $\mathrm{TB}$ patients require more time for conversion than $\mathrm{AFB}+2$ and $\mathrm{AFB}+1$.

The results of this study prove that vitamin D significantly accelerates sputum conversion in TB patients. Provision of vitamin D in TB patients is highly recommended as one way to break the chain of TB infection. Vitamin D supplementation can increase the immune system of TB patients by inducing the production of cathelisidin which plays a role in fighting TB germs. ${ }^{(28-30)}$

\section{CONCLUSION}

Vitamin D supplementation accelerates the sputum conversion of TB patients with the recommended supplementation time of 4 to 6 weeks.

\section{REFERENCES}

1. Report W. Global Tuberculosis Report 2019 [Internet]. France: WHO/CDS/TB/2019.15; 2019. 2-3,2223,27,31-68 p. Available from: http://apps.who.int/iris.

2. Balitbangkes Kemenkes RI. Basic Health Research 2018 (Riset Kesehatan Dasar / RISKESDAS 2018) [Internet]. Badan Penelitian dan Pengembangan Kesehatan Kementerian Kesehatan Republik Indonesia. 2018 [cited 2019 Jan 1]. Available from: http://www.depkes.go.id/resources/download/info-terkini/hasilriskesdas-2018.pdf

3. Badan Pusat Statistik Pejabat Pengelola Informasi dan Dokumentasi. List of Public Information (Daftar Informasi Publik) [Internet]. Kereta Api. 2018 [cited 2019 Jan 1]. Available from: https://kip.keretaapi.co.id/daftar-informasi

4. Nursyam EW, Amin Z, Rumende CM. The effect of vitamin D as supplementary treatment in patients with moderately advanced pulmonary tuberculous lesion. Acta Med Indones. 2006;38(1):3-5.

5. Siswanto, Sumarno, Jane Yani, Widayanti Oeryana A MNS. Vitamin D as Supportive Treatment Improve The Sputum Conversion and Radiographic Finding in Tuberculosis Patients (Pengobatan Suportif Vitamin D Mempercepat Konversi Sputum dan Perbaikan Gambaran Radiologis Penderita Tuberkulosis). Kedokt

51 | Publisher: Humanistic Network for Science and Technology 
Brawijaya. 2009;25(3):128-32.

6. Pratiwi RD, Pramono D, Iswanto I, Junaedi J. Supplementation of Vitamin A and D in the Medication of Lung Tuberculosis. Int J Public Heal Sci. 2017;6(1):87.

7. Selvaraj P, Vidyarani M, Alagarasu K, Prabhu Anand S, Narayanan PR. Regulatory role of promoter and 3' UTR variants of vitamin D receptor gene on cytokine response in pulmonary tuberculosis. J Clin Immunol. 2008;28(4):306-13.

8. Nugroho HSW. Descriptive Data Analysis for Categorical Data (Analis Data Secara Deskriptif untuk Data Kategorik). Ponorogo: Forum Ilmiah Kesehatan (FORIKES); 2014.

9. Seo IY, Kang IH, Chae SC, Park SC, Lee YJ, Yang YS, et al. Vitamin D Receptor Gene Alw I, Fok I, Apa I, and Taq I Polymorphisms in Patients With Urinary Stone. Urology. 2010;75(4):923-7.

10. Chen C, Liu Q, Zhu L, Yang H, Lu W. Vitamin D receptor gene polymorphisms on the risk of tuberculosis, a meta-analysis of 29 case-control studies. PLoS One. 2013;8(12):1-11.

11. HADDAD S. Vitamin-D receptor (VDR) gene polymorphisms (Taq-I \& Apa-I) in Syrian healthy population. Meta Gene [Internet]. 2014;2:646-50. Available from: http://dx.doi.org/10.1016/j.mgene.2014.08.005

12. Rosenberg IH. Challenges and opportunities in the translation of the science of vitamins. Am J Clin Nutr. 2007;85(1):325-7.

13. Sinaga BYM, Amin M, Siregar Y, Sarumpaet SM. Correlation between Vitamin D receptor gene FOKI and BSMI polymorphisms and the susceptibility to pulmonary tuberculosis in an Indonesian Batak-ethnic population. Acta Med Indones. 2014;46(4):275-82.

14. Report WHO. Global Tuberculosis Control: WHO Report 2011. Aust N Z J Public Health. 2012;36(5):497-8.

15. Donald PR, Marais BJ, Barry CE. Age and the epidemiology and pathogenesis of tuberculosis. Lancet. 2010;375(9729):1852-4.

16. Sutaria N, Liu CT, Chen TC. Vitamin D status, receptor gene polymorphisms, and supplementation on tuberculosis: A systematic review of case-control studies and randomized controlled trials. J Clin Transl Endocrinol [Internet]. 2014;1(4):151-60. Available from: http://dx.doi.org/10.1016/j.jcte.2014.08.001

17. Chocano-Bedoya P, Ronnenberg AG. Vitamin D and tuberculosis. Nutr Rev. 2009;67(5):289-93.

18. Kochupillai N. The physiology of vitamin D: Current concepts. Indian J Med Res. 2008;127(3):256-62.

19. Joel M. Kauffman. Benefits of Vitamin D Supplementation. J Am Physicians Surg. 2009;14(2):38-45.

20. Lawn SD, Zumla AI. Tuberculosis. Lancet. 2011;378(9785):57-72.

21. Setiabudiawan B. The role of vitamin D deficiency and Fok1 Bsm1 Apa1 Taq1 polymorphism in pediatric TB (Peran defisiensi vitamin D dan polimorfisme Fok1 Bsm1 Apa1 Taq1 terhadap TB anak). Sari Pediatr. 2010;11(5):317-25.

22. Salahuddin N, Ali F, Hasan Z, Rao N, Aqeel M, Mahmood F. Vitamin D accelerates clinical recovery from tuberculosis: Results of the SUCCINCT Study [Supplementary Cholecalciferol in recovery from tuberculosis]. A randomized, placebo-controlled, clinical trial of vitamin D supplementation in patients with pulmonar. BMC Infect Dis [Internet]. 2013;13(1):1.

23. Talat N, Perry S, Parsonnet J, Dawood G, Hussain R. Vitamin D deficiency and tuberculosis progression. Emerg Infect Dis. 2010;16(5):853-5.

24. Dini, C and Bianchi A. The potential role of vitamin D for prevention and treatment of tuberculosis and infectious diseases. Ann Ist Super Sanità. 2011;47(4):363-72.

25. Parikh R, Nataraj G, Kanade S, Khatri V, Mehta P. Time to sputum conversion in smear positive pulmonary TB patients on category I DOTS and factors delaying it. J Assoc Physicians India. 2012;60(8):22-6.

26. Ditjen P2\&PL Kemenkes RI. Breakthrough Towards Universal Access, National Strategy for TB Control in Indonesia 2010-2014: Stop TB(Terobosan Menuju Akses Universal, Strategi Nasional Pengendalian TB di Indonesia 2010-2014: Stop TB) [Internet]. World Health Organization. 2011 [Cited 2019 Jan 1]. Available from: http://www.searo.who.int/indonesia/topics/tb/stranas_tb-2010-2014.pdf

27. Susanti D. Acid-Resistant Basil (BTA) Examination in Sputum for Cough Patients $\geq 2$ Weeks in Internal Medicine Polyclinic, BLU Hospital. PROF. Dr. R.D Kandou Manado (Pemeriksaan Basil Tahan Asam (BTA) pada Sputum Penderita Batuk $\geq 2$ Minggu di Poliklinik Penyakit Dalam, BLU RSUP. PROF. Dr. R.D Kandou Manado). e-CliniC. 2013;1(1):1-5.

28. Babb C, van der Merwe L, Beyers N, Pheiffer C, Walzl G, Duncan K, et al. Vitamin D receptor gene polymorphisms and sputum conversion time in pulmonary tuberculosis patients. Tuberculosis. 2007;87(4):295-302.

29. Martineau AR, Timms PM, Bothamley GH, Hanifa Y, Islam K, Claxton AP, et al. High-dose vitamin D3 during intensive-phase antimicrobial treatment of pulmonary tuberculosis: A double-blind randomised controlled trial. Lancet. 2011;377(9761):242-50.

30. Coussens AK, Wilkinson RJ, Hanifa Y, Nikolayevskyy V, Elkington PT, Islam K, et al. Vitamin D 
accelerates resolution of inflammatory responses during tuberculosis treatment. Proc Natl Acad Sci U S A. 2012;109(38):15449-54. 